\title{
$\mathrm{C}|\mathrm{E}| \mathrm{D}|\mathrm{L}| \mathrm{A} \mid \mathrm{S}$
}

Centro de Estudios

Distributivos, Laborales y Sociales

Maestría en Economía

Universidad Nacional de La Plata

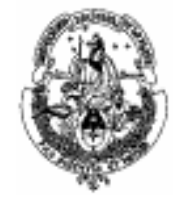

\section{Sources of Income Persistence: Evidence from Rural El Salvador}

\author{
Walter Sosa-Escudero, Mariana Marchionni y Omar \\ Arias
}

Documento de Trabajo Nro. 37

Junio, 2006 


\title{
Sources of Income Persistence: Evidence from Rural El Salvador
}

\author{
Walter Sosa-Escudero, Mariana Marchionni, and Omar Arias ${ }^{1}$
}

May 2006

\begin{abstract}
This paper uses a unique panel dataset (1995-2001) of rural El Salvador to investigate the main sources of the persistence and variability of incomes. First we propose an econometric framework where a general dynamic panel model is validly reduced to a simple linear structure with a dynamic covariance structure, which augments considerably the number of degrees of freedom usually lost in the construction of instruments to estimate standard dynamic panel models. Then we investigate the extent to which families are continuously poor due to endowments (observed and unobserved) that yield low income potential or due to systematic income shocks that they are unable to smooth. We find that life-cycle incomes are largely explained by the relatively time-invariant productive characteristics of families and their members such as education, public goods and other assets. Observed income determinants account for about half of income persistence. Controlling for unobserved heterogeneity leaves little room for pure state dependence. Although of second order, high volatility and the inability to insure from shocks is a more important source of variation in incomes than in developed countries. Low income potential is the more likely source of poverty traps in Rural El Salvador. Many of the family endowments are manipulable by policy interventions, although many not in the short term.
\end{abstract}

Key Words: Income mobility, Poverty Traps, Panel Data, El Salvador.

JEL code: I32

1 Corresponding author: Walter Sosa-Escudero, Associate Professor, Department of Economics, University of San Andres, Vito Dumas 284, B1644BID Victoria, Argentina, Ph/Fax: (54-11) 4725-7024, e-mail: wsosa@udesa.edu.ar. Mariana Marchionni is Assistant Professor and researcher at CEDLAS, National University of La Plata, mariana@depeco.econo.unlp.edu.ar. Omar Arias is a Senior Economist at the Poverty and Gender Group of the Latin American and Caribbean Department of the World Bank, oarias@worldbank.org. Conclusions, errors and omissions are the sole responsibility of the authors. 


\section{Introduction}

Despite significant structural economic reforms growth has been scant and poverty and inequality remain high and deep-rooted in Latin America and the Caribbean (LAC henceforth). Around 40 percent of the region's population has lived in poverty measured according to country-specific living standards since the mid-1990s. ${ }^{2}$ And because of population growth the number of poor actually increased in the early 2000 s.

A key question for public policy is whether this lack of progress in poverty results from the persistence of poverty in the same families or from movements in-andout of poverty of different families. Income deprivation is perceived as a greater concern when it is persistent over time rather than transitory. Moreover, policy interventions should have a different emphasis depending on which is the main source of low-income persistence; poverty due to high income volatility calls for interventions to reduce and insure risks while poverty arising from insufficient endowments requires policies to increase income potential.

This issue concerns the literature of intergenerational income mobility and more recently of poverty vulnerability. In essence both address the question: how likely is it that a household of given characteristics finds itself in poverty at a given future time? The answer ultimately depends on the long-term consumption prospects and consumption volatility faced by a household. That is, a household can be persistently poor due to endowments that yield low income potential and/or due to income shocks that it is unable to smooth. Thus, income persistence depends on the state and evolution of household characteristics (observed and unobserved) and of the aggregate environment.

The subject naturally requires data following households over a relatively long time span, which has hindered research in Latin America. ${ }^{3}$ To this purpose, this paper uses a unique panel dataset (1995-2001) for rural El Salvador to investigate the main sources of the persistence and variability of incomes, offering a valuable opportunity to study these issues in Latin America. The country achieved considerable improvements in poverty and other living conditions indicators during the 1990s. Rural poverty fell by 20 points according to official data (World Bank 2005). Recent studies (See World Bank 2005) have shown that much of this progress is related to a significant economic

\footnotetext{
${ }^{2}$ This figure is based on national poverty lines (the cost of country specific baskets of basic food and nonfood consumption) estimated in the Socio-economic Database for Latin America and the Caribbean (SEDLAC) maintained by the LAC World Bank poverty group and the Center for Distributional, Labor and Social Studies (CEDLAS) of the University of La Plata in Argentina (see World Bank 2006 and www.depeco.econo.unlp.edu.ar/cedlas).

${ }^{3}$ For recent studies for Africa see Barrett, Carter and Little (forthcoming).
} 
diversification from traditional agriculture (i.e., basic grains, coffee and sugar) to offfarm productive activities, important investments in rural infrastructure that improved access to markets, and an important inflow of international remittances. Notwithstanding, El Salvador was affected by several shocks, particularly sequels of the Mitch storm, the drought caused by the El Niño effect, two earthquakes, and a fall in coffee export prices. Half of Salvadorians in rural areas remain poor and a quarter live in mere subsistence. Thus, El Salvador offers important insights on the mechanics of income and poverty dynamics in a context of significant poverty reduction driven by private strategies and public investments.

From a methodological point of view, this paper uses a linear specification similar to that used in the classic Lillard and Willis (1978) study, where the relevant dynamic components are modeled as part of the covariance structure of a linear panel data model. A methodological contribution of this paper is to show that this particular specification is a valid restriction of a general dynamic panel linear model. The main advantage of adopting this simplification is the considerable savings in terms of degrees of freedom arising from the fact that the dynamic covariance structure can be handled by a simple method-of-moments, unlike standard linear dynamic panels which require instrumental variables implying a considerable loss in degrees-of-freedom, a much relevant issue when, as in our case, the time dimension of the problem is short. The paper uses the framework proposed by Bera, Sosa-Escudero and Yoon (2001) to formally test the relevance of the dynamic covariance model.

The paper is organized as follows. The next section presents a brief review of the relevant literature. Section 3 describes the panel data set used. Section 4 discusses the econometric strategy used in the paper. Sections 5 and 6 discuss the results of the econometric analysis and some simple exercises that help interpret them. Section 7 concludes and highlights the main implications for public policy.

\section{The empirical evidence on income persistence}

Taking household income as determined by the retribution to the use of all the assets owned by a family, life-cycle incomes reflect the evolution of these assets, their pricing, and how both are affected by economic and other shocks. Friedman and Kuznets (1954) first proposed the decomposition of the determination of incomes over time into permanent and transitory components, which became later embedded in Friedman's permanent income hypothesis. Since then the intergenerational income mobility literature has focused on the role of assets and their returns to explain longterm income persistence and has been much more common in developed countries 
where longer panel data allows studying this phenomenon. As exemplified below, the strand of studies on poverty vulnerability is more common in developing countries where short panels or cross-section data have been used to examine the link between poverty and the inability to smooth out the kinds of shocks that are prevalent in regions like LAC.

In their seminal work, Lillard and Willis (1978) conducted a careful empirical study of life cycle earnings mobility using U.S. data from the Panel Survey of Income Dynamics (PSID), clearly rooted in Friedman and Kuznets' framework. They developed and estimated a dynamic reduced form model of earnings with a deterministic component consisting of a trend, a vector of observed family characteristics and an unobserved family specific effect, as well as a transitory shock modeled as a first order autoregressive process. The permanent component reflects a family's long-term income potential related to its productive characteristics such as human capital, other assets, and family specific unmeasured skills. The transitory component captures external factors such as economic swings, idiosyncratic shocks, or plain measurement errors, which make incomes depart from their permanent level. Their main findings are that low earnings at early ages are strong predictors of low earnings later in life, even conditioning on observed individual characteristics, and that income shocks ("bad luck") have a secondary role in explaining long-term income mobility. They found that in a given year, most of the variance in earnings not accounted for by family and individual factors (such as race, education and age) is due to transitory shocks, but that over a lifetime the bulk of income persistence is due to unobserved individual heterogeneity.

These key results have endured different estimation and testing methods and studies, and updated data sets. The seminal work of MaCurdy (1982) shows that earnings from the PSID are best described by the sum of a random walk and an MA(1) component. Abowd and Card (1989), Gottschalk and Moffitt (1994), Meghir and Pistaferri (2002), as well as more recent applications using semiparametric and Bayesian methods (Horowitz and Markatou (1996); Geweke and Keane (2000)) find similar results and further develop these ideas.

A parallel literature on vulnerability has analyzed similar issues in terms of families' future consumption prospects for given endowments (observed and unobserved) and the risks to actually materialize those prospects. Examples are Chaudhuri, Jalan and Suryahadi (2002), Chaudhuri (2000), Pritchett, Suryahadi and Sumarto (2000), Jalan and Ravallion (1999), and Ravallion and Chaudhuri (1997). 
The absence of mobility or inability to recover from severe shocks also lie in the realms of the poverty traps literature where individuals, communities, or even nations are unable to escape from poverty or a low level of development (Azariadis and Stachurski, 2005). This may occur due to the presence of a minimum scale of production before an investment becomes profitable, credit constraints or excessive underinsured risk under imperfect financial markets, or the inability to exploit complementarities in production between human, physical, or social assets. Lokshin and Ravallion (2004) examine income dynamics in Hungary and Russia using a six year and four year panels, respectively, and they propose a simple way of identifying poverty traps. They estimate the degree to which the relationship between present and past incomes involves a polynomial function that embeds a hump or income threshold below which families become "trapped" in a low income equilibrium. They find significant evidence of nonlinearities in income dynamics in these two countries, but no evidence of dynamic poverty traps, that is, of a threshold income level below which income deprivation persists. Their results also highlight that measurement error in incomes, which are likely aggravated in short data panels, is likely to cause spurious negative correlation between income changes and initial levels. More recently, Newhouse (2005) estimates the persistence of transient income shocks in rural Indonesia and found that more permanent causes of household poverty such as endowments are more significant and that measurement error in income and unobserved household heterogeneity are important sources of bias.

As stressed in the introduction, the analysis of these issues in Latin America and the Caribbean has been scant due to insufficient panel data. For instance, Fields et. al. (2005) use panel data for Argentina, Mexico and Venezuela, to examine changes in individual earnings during one to two year spells of positive and negative economic growth. They find limited evidence (except somewhat for Mexico) for what they call "divergent mobility", by which those that start off relatively better off experience the largest earnings gains or smallest income losses. Their results are thus inconsistent with poverty traps. To our knowledge Freije and Souza (2002) is the only study that uses the Lillard and Willis (1978) methodology to analyze income mobility in the region. They use a two-year panel for Venezuela and found that, in any given year, the majority of variation in incomes is not accounted for by education or observed family characteristics but instead is due to transitory shocks. That is, volatility is the major source of variation in incomes across families, contrary to the findings for developed countries.

However, a problem plaguing this and related studies in LAC is their reliance on labor market panel surveys spanning over no longer than 2 years. This means that they 
are likely to disproportionately capture measurement error or short term income variation rather than the longer term income mobility of prime interest in the intergenerational mobility and poverty traps literature. This is confirmed in the studies by Lokshin and Ravallion (2004) and Newborne (2005).

Two recent studies have tried to circumvent this problem. Rodríguez-Meza and González-Vega (2004) study income dynamics and test for the presence of poverty traps using the same 7 year panel data for El Salvador we use in this paper. They adopt an approach similar to Lokshin and Ravallion (2004) and found evidence of non-linearities in income dynamics consistent with the existence of poverty traps. Although higher income families in rural areas recover very quickly from an income shock the poor face a much longer time to recover. In fact, the prospects of very low income families (ie., in extreme poverty) to escape subsistence levels become very dim after being hit by a catastrophic income shock. This result, however, might not be robust since, as the findings of Lokshin and Ravallion (2004) attest, tests of highly non-linear income processes that use a few years of panel data are likely to have reduced power to distinguish among alternative income dynamic specifications. Another approach proposed by Antman and Mckenzie (2005) relies on pseudo panels to track cohorts over repeated cross sectional surveys to measure income mobility among "representative" individuals moving across time. This approach effectively averages out transitory shocks across an entire cohort thus correcting for measurement error in incomes. They find little evidence for poverty traps in Mexico and significantly lower measured mobility in the pseudo panels compared to the actual panel transitions. However, none of these two studies explicitly analyze the relative contribution of the permanent and transitory income components to income mobility or the persistence of low income states.

In this paper we reexamine the question of income mobility exploiting the advantages of the longer-span of panel data for El Salvador and the parsimonious linear dynamic income model of Lillard and Willis (1978). We test and find supporting evidence that this conveniently simplified model is an econometrically valid reduction that uses more efficiently the relatively longer but still short span of data. Moreover, the proposed framework allows a richer investigation of a number of policy-relevant questions such as do families starting with a low income status in 1995 in El Salvador have a high chance of still being low income in 2001? Which factors make low income states to be transitory for some households and permanent for others? How much hinges on idiosyncratic and transitory characteristics of families (measured and unmeasured) or unexploited externalities like absent public goods and how much on external shocks or fortune? We now turn to the data and econometric model to address these questions. 


\section{The data}

We use data from the rural panel survey (BASIS hereafter) conducted by the Fundación Salvadoreña para el Desarrollo Económico y Social (FUSADES) and the Rural Finance Program at the Ohio State University (OSU). The survey collects data on incomes, demographic, occupational, access to credit and physical assets (e.g., infrastructure, land, housing) among other characteristics of rural households and their strategies to cope with risk (for further details on the survey and data see Rodríguez-Meza and González-Vega (2004)). The panel data set is composed of four biennial observations for the years 1995, 1997, 1999, and 2001. While still a limited time span, this is a major improvement over the one to two year panels that have been used to study mobility in LAC.

In 1995, 628 households were interviewed while in 2001 only 450 of the original households remained in the panel, reflecting an accumulated attrition rate of 28 percent. More than 75 percent of the attrition occurred from the first to second wave when it was decided the survey would be continued as a panel. We focus the analysis on households since this is a more relevant unit of analysis for assessing intergenerational income mobility and also minimizes concerns arising from panel attrition which is more prevalent among individuals. A total of 449 households are observed in all four years, but we have complete information only for 409 which will be the main sample used in our analyses.

The evolution of incomes has been more favorable for off-farm income sources. Table 1 shows the level and growth rate of annual per capita income at different percentiles of the household income distribution (using only the cross-section structure of the data). Between 1995 and 2001, the average family per capita income grew at an average rate of $8 \%$ per year The evolution of incomes has been relatively more favorable for the poor among agrarian households. 
Table 1. Evolution of annual per capita income of Rural Households in El Salvador

(in 2001 colones)

\begin{tabular}{|l|r|r|r|r|r|}
\hline \multirow{2}{*}{ Summary Statistics } & \multicolumn{5}{|c|}{ 409 households in estimation sample } \\
\cline { 2 - 6 } & \multicolumn{1}{|c|}{1995} & 1997 & 1999 & 2001 & $\begin{array}{r}\text { Average } \\
\text { annual } \\
\text { growth }\end{array}$ \\
\hline Mean & 4105.35 & 3975.02 & 5911.67 & 6490.64 & $7.93 \%$ \\
& 612.79 & 483.62 & 741.43 & 896.43 & $6.55 \%$ \\
10th percentile & 1355.06 & 1225.60 & 1653.00 & 2235.07 & $8.70 \%$ \\
25th percentile & 2710.12 & 2629.86 & 3637.97 & 4224.43 & $7.68 \%$ \\
50th percentile (median) & 5084.01 & 5427.63 & 7113.33 & 7928.72 & $7.69 \%$ \\
75th percentile & 8304.77 & 8943.17 & 13081.99 & 13362.00 & $8.25 \%$ \\
90th percentile & 5575.45 & 4645.11 & 7089.32 & 8071.50 & \\
Standard deviation & & & & & \\
\hline
\end{tabular}

\begin{tabular}{|c|c|c|c|c|c|c|c|c|c|c|}
\hline \multirow[b]{2}{*}{ Summary Statistics } & \multicolumn{5}{|c|}{ Agrarian households in estimation sample } & \multicolumn{5}{|c|}{ Non-Agrarian households in estimation sample } \\
\hline & 1995 & 1997 & 1999 & 2001 & $\begin{array}{l}\text { Average } \\
\text { annual } \\
\text { growth }\end{array}$ & 1995 & 1997 & 1999 & 2001 & $\begin{array}{l}\text { Average } \\
\text { annual } \\
\text { growth }\end{array}$ \\
\hline Mean & 3431.09 & 2862.13 & 4168.28 & 4554.93 & $4.84 \%$ & 5346.20 & 5724.84 & 8387.50 & 8614.96 & $8.28 \%$ \\
\hline 10th percentile & 351.63 & 221.14 & 430.01 & 581.50 & $8.75 \%$ & 1559.40 & 1470.55 & 2244.17 & 2324.17 & $6.88 \%$ \\
\hline 25th percentile & 1031.63 & 784.72 & 1169.21 & 1303.67 & $3.98 \%$ & 2594.20 & 2440.57 & 3726.98 & 3765.00 & $6.40 \%$ \\
\hline 50th percentile (median) & 2088.30 & 1824.76 & 2405.69 & 2696.41 & $4.35 \%$ & 4399.25 & 4660.83 & 6434.76 & 6495.00 & $6.71 \%$ \\
\hline 75th percentile & 4012.64 & 3449.50 & 4836.84 & 4608.00 & $2.33 \%$ & 6392.63 & 6938.10 & 10173.05 & 9976.24 & $7.70 \%$ \\
\hline 90th percentile & 7386.97 & 6234.80 & 8540.59 & 9456.05 & $4.20 \%$ & 9937.85 & 10499.44 & 15985.97 & 15336.00 & $7.50 \%$ \\
\hline Standard deviation & 5806.09 & 3898.06 & 5744.42 & 7286.53 & & 4905.49 & 5170.17 & 8037.65 & 8369.70 & \\
\hline
\end{tabular}

Source: Own estimates based on BASIS (1995-2001).

Numerous analyses with this dataset indicate that assets endowments (land, education), access to markets and infrastructure (road, credit), household risk coping strategies (productive diversification, microenterprise development, remittances), and household demographics (size, composition, gender) all affect family income growth. ${ }^{4}$ In this paper we focus on the sources of income persistence, and thus on what explains that some families are able to experience more income mobility than others.

\section{Econometric modeling of income persistence}

The relatively short time span of the panel casts some doubts on the adequacy of standard dynamic panel model analysis of these data. This section discusses a convenient simplification that, under valid restrictions, can be informative about the questions of this paper while using the available information efficiently.

\footnotetext{
${ }^{4}$ See Tannuri-Pianto, Pianto, Arias and Beneke de Sanfeliu (2005), Beneke de Sanfeliu and Shi (2004), Rodríguez-Meza and González-Vega (2003, 2004), and Lanjouw (2001).
} 
Let $\mathrm{y}_{i, t}$ denote income of household $i$ in period $t$. When incomes are stationary, a simple measure of short term persistence is the (unconditional) correlation of incomes between adjacent periods, $\operatorname{Cor}\left(y_{i, t}, y_{i, t-1}\right)$. A basic goal of the analysis is to compare this total correlation with the partial correlation that arises after controlling for exogenous determinants (family specific or not) and non-observed family specific factors. A standard specification that accommodates all these factors is the linear dynamic equation:

$$
y_{i}=\gamma y_{i, t-1}+x_{i, t^{\prime}} \beta_{0}+x_{i, t-1}{ }^{\prime} \beta_{1}+\mu_{i}+\varepsilon_{i t}
$$

where $i=1, \ldots, N$ households, and $t=1, \ldots, T$, periods, $x_{i, t}$ is a $K$ vector of observed exogenous determinants of income, $\mu_{\mathrm{i}}$ is a zero mean random variable representing unobserved, family specific terms, and $\varepsilon_{\text {it }}$ is a white noise process representing family and time specific unobserved shocks. ${ }^{5}$

A relatively well established fact is that empirical models for individual and family income have a rather low explanatory power even when a rich micro-data base is used, which renders unobservable "error terms" as very important determinants of income. ${ }^{6}$ These include family specific, non-measured variables like, for example, unmeasured skills, preferences, and risk aversion, which is associated with unobserved heterogeneity in panel models and generally considered to be persistent over time. Time-variant-family-specific shocks can also be persistent. For example, it takes time to recover from a job loss or death of a family working member or to rebuild human capital that due to sudden changes in technology becomes quickly obsolete. These can generate "state dependence", that is, an income fall in a low income state in a given period increases the chances of being low income in subsequent periods.

An important aspect of the analysis is to distinguish between these different sources of income persistence given their distinct policy implications. Persistence due to insufficient endowments (observed and unobserved) requires policies to increase income potential such as health, educational and infrastructure investments. Persistence of shocks under high income volatility calls for interventions to reduce and insure risks such as safety nets and improved access to financial markets.

\footnotetext{
5 This model has also found applications in the literature of persistence of regional unemployment literature. See Blanchard and Katz 1992 and more recently Galiani, Lamarche, Porto and Sosa-Escudero 2005 .

6 Finis Welch has referred to the residual as "my favorite source of wage variance" (Welch, 1999, In defense of inequality, AER Papers and Proceedings, page 2).
} 
Estimates of (1) can provide a measure of what part of total income persistence remains when various sources of persistence are accounted for since $\gamma$ is a partial correlation. ${ }^{7}$ Consistent estimation of the parameters $\gamma, \beta_{0}$ and $\beta_{1}$ has been well studied in the econometrics literature. The case when $\gamma$ is different from zero renders standard estimators inconsistent requiring alternative strategies like GMM methods (Arellano and Bond 1991). Moreover, there is ample evidence on the poor sample performance of GMM based estimators (e.g., Judson and Owen 1999) in terms of bias and efficiency when $\mathrm{T}$ is small. This highlights the relevance of adopting valid simplifications to increase the reliability of estimates in our case where only four time-observations are available.

In their seminal paper Lillard and Willis (1978) proposed a very appealing approach that relies on autocorrelated models as convenient simplifications of more general dynamic structures, much in the spirit of the classic paper by Hendry and Mizon (1978). Consider a simple linear panel data model with first order autocorrelation:

$$
\begin{gathered}
y_{i t}=x_{i t}{ }^{\prime} \delta+\mu_{i}+v_{i t} \\
v_{i t}=\varphi \quad v_{i, t-1}+\varepsilon_{i t,} \quad|\varphi|<1
\end{gathered}
$$

where $\mu_{i} \sim$ iid $\left(0, \sigma_{\mu}^{2}\right), \varepsilon_{i t} \sim$ iid $\left(0, \sigma_{\varepsilon}^{2}\right)$, independent of each other and of $x_{i t}$. In this specification the potential sources of persistence are $\mathrm{x}_{\mathrm{it}}, \mu_{\mathrm{i}}$ and the presence of serial correlation in the observation specific error process. The vector $\mu_{\mathrm{i}}$ represents in our case family-specific unobserved heterogeneity, and the serially correlated structure in the error term represents 'state dependence' of the shocks to family incomes. This is basically the same setup used in Lillard and Willis (1978) and we refer to this paper for further references. The parameters of this model can be estimated by maximumlikelihood methods under suitable distributional assumptions, as in Lillard and Willis (1978), or by relying on the method of moments as in Baltagi (2001, pp.82-83).

It can be readily verified that the serially correlated model in (2)-(3) is a particular, testable restriction of the linear dynamic model in (1). Substract $\varphi y_{i, t-1}$ in both sides of (2) and simplify using (3) to get:

\footnotetext{
${ }^{7}$ For instance, in their analysis of regional unemployment in Argentina Galiani et al. (2005) found that "true" persistence in unemployment $(\gamma)$ is much lower than total persistence after several determinants of regional unemployment are considered.
} 


$$
y_{i t}=\varphi y_{i, t-1}+x_{i t}{ }^{\prime} \delta-\varphi x_{i, t-1}{ }^{\prime} \delta+(1-\varphi) \mu_{i}+\varepsilon_{i t}
$$

This is basically model (1) with the non-linear restrictions:

$$
-\beta_{1 k} / \beta_{0 k}=\gamma, \quad k=1, \ldots, K
$$

which can be subject to standard Wald-type tests after estimating the unrestricted model. The practical advantages of considering these restrictions implicit in Lillard and Willis (1978) is that their model can be estimated using $N(T-1)$ observations, whereas the differencing and instrument construction process of GMM related estimators is based on $N(T-3)$ observations, which would infringe a significant loss of degrees of freedom in the El Salvador data set.

A convenient advantage of the simple structure implicit in (2)-(3) is that measures of the variation and persistence of incomes can be conveniently summarized in a simple parametric fashion. Let the composite unobservable error terms be $u_{i t} \equiv \mu_{i}+$ $v_{i t}$, and let $\sigma^{2}{ }_{v}$ denote the variance of $v_{i t}$, which, given the $\operatorname{AR}(1)$ structure of $v$, is given by $\sigma^{2}{ }_{v}=\sigma_{\varepsilon}^{2} /\left(1-\varphi^{2}\right)$. Hence the total variation in incomes arising from unobservable factors is $\sigma_{u}^{2}=\sigma_{\mu}^{2}+\sigma_{v}^{2}=\sigma_{\mu}^{2}+\sigma_{\varepsilon}^{2} /\left(1-\varphi^{2}\right)$. Also $\lambda \equiv \sigma_{\mu}^{2} / \sigma_{u}^{2}$ measures the relative importance of the family specific components in the overall variance of the error term. Another magnitude of interest is the autocorrelation of the overall error term, which can be easily verified to be given by:

$$
\rho_{s} \equiv \operatorname{Cor}\left(u_{i t}, u_{i, t-s}\right)=\lambda+(1-\lambda) \varphi^{s}
$$

Hence, income persistence arising from unobservables is an average of the persistence induced by family-specific time invariant factors and period specific shocks, weighted by their relative importance in explaining income variations. If $\sigma_{\varepsilon}^{2}=0$ the pairwise temporal correlation of the composite error terms is trivially one (due to the presence of unobserved heterogeneity), whereas if $\sigma_{\mu}^{2}=0$ the only correlation left is the one induced by the serially correlated, observation specific income shock. This means that if the interest lies in persistence, the relative importance of each source depends on how large is the persistence of each source and how important is that particular source in explaining income disparities. In a model without explanatory variables $\rho_{s}$ measures 
overall income persistence. The inclusion of explanatory variables has the effect of netting out the income persistence induced by observable income determinants.

Tests of the restrictions embodied in (2)-(3) can be conducted under the comprehensive testing framework for serially correlated models with unobserved heterogeneity of a recent study by Bera, Yoon and Sosa Escudero (2001). Their proposed tests are conveniently based on estimation under the joint null $\sigma_{\mu}^{2}=0$ (no random effects) and $\varphi=0$ (no serial correlation) by pooled OLS. Additionally, they correctly detect whether persistence is due to the presence of unobserved heterogeneity, serially correlated shocks or both, unlike standard tests which confound one effect with the other. For example, the standard Breusch-Pagan test for random effects tends to reject the null hypothesis under the presence of unobserved heterogeneity and/or the serial correlation, which makes it unattractive to detect which is the main source of persistence. The fact that Bera et al's procedure is based on pooled OLS using N(T-1) observations should increase testing power compared to direct estimation of the full dynamic model to test $\mathrm{H}_{0}: \gamma=0$ (no dynamic effect) using $\mathrm{N}(\mathrm{T}-3)$ observations. Still, this would require the implementation of an appropriate test for $\mathrm{H}_{0}: \sigma_{\mu}^{2}=0$ (no unobserved heterogeneity).

Consequently, our empirical strategy consists of the following steps:

1. Start by implementing the Bera et al. (2001) testing procedure to elucidate the validity of the stochastic restrictions in (2)-(3), that is, whether one or both sources of persistence are present. We estimate a model under the joint null hypothesis. Recent work by Zincenko (2005) shows that the modified test of Bera et al. (2001) has power in the direction of $\mathrm{H}_{\mathrm{A}}: \gamma=0$ in the dynamic model.

2. Under the presence of dynamic effects, the dynamic model will be estimated with the purpose of obtaining a basic set of estimates of the relevant parameters and to test the non-linear restrictions described above.

3. Under the null of valid restrictions, the Lillard-Willis (1978) simplification will be adopted, and the full error component with serial correlation will be estimated using the method-of-moments approach described in Baltagi (2001). This strategy provides estimates of all the parameters of interest.

A remaining concern is the bias arising from sample attrition (individuals/families dropping from the panel) due to the correlation between the income error terms and the probability of staying in the panel. For instance, households 
suffering catastrophic income shocks may be more likely to breakup or more risk-taking families may be more likely to migrate, which could lead to dropping out of the panel survey. As highlighted by Lokshin and Ravallion (2004) this is an important potential source of biases in this type of analysis. The attrition rate is 28 percent among families, and largely occurred from the first to second wage when it was decided the survey would be continued as a panel. The evidence from previous studies indicates that this does not appear to affect significantly the sample composition and the validity of statistical inference from this sample (see Rodríguez-Meza and Gonzalez-Vega 2004).

\section{Empirical results}

Following the previous studies using these data, the empirical models include a multitude of characteristics standard in the literature of microdeterminants of family incomes. In particular, we follow closely the empirical specifications recently adopted by Tannuri-Pianto, Pianto, Arias and Beneke de Sanfeliu (2005) who carry a comprehensive study of the microdeterminants of household per capita income with these data. The regressors include household characteristics such as average years of education, family composition, workers per capita, proximity to markets (proxied by the distance to a paved road), access to credit, degree of diversification, other income sources and region of residence. We also control for overall income trends through time dummies. We also consider interdependencies (e.g., complementarities, threshold effects) in the determinants of incomes by including interactions of selected explanatory variables, for example, between education and distance to a paved road. Definitions and descriptive statistics of variables are reported in the Appendix (Tables A.1 and A.2).

We consider four alternatives for estimating the model, which add explanatory variables progressively (see Table A.3 for more detail):

Model 1: only time dummies

Model 2: adds basic educational and demographic characteristics and geographic controls.

Model 3: adds other household economic characteristics

Model 4: adds several interactions between explanatory variables

A first step consisted in implementing the tests proposed by Bera et al. (2001) to explore the presence of unobserved family random effects and serially correlated observation specific error terms. Results are presented in Table 2 and strongly suggest 
the presence of both sources of persistence. We also estimated the linear dynamic model and tested whether the non-linear restrictions implicit in the Lillard and Willis (1978) model are appropriate. The Wald tests do not provide evidence against this simplification, though care must be taken given the possible low power of such procedures. The results thus justify considering the joint presence of persistence due to unmeasured, time invariant, family characteristics and serially correlated shocks.

Table 2: Tests for error components Bera et al. (2001)

\begin{tabular}{|c|c|c|c|c|c|c|c|c|}
\hline \multirow{2}{*}{ Tests } & \multicolumn{2}{|c|}{ Model 1} & \multicolumn{2}{|c|}{ Model 2} & \multicolumn{2}{|c|}{ Model 3} & \multicolumn{2}{|c|}{ Model 4} \\
\hline & statistic & p-value & statistic & p-value & statistic & p-value & statistic & p-value \\
\hline \multicolumn{9}{|l|}{ Individual Random Effect } \\
\hline LM $(\operatorname{Var}(\mathrm{u})=0)$ & 147.45 & 0.0000 & 37.96 & 0.0000 & 19.77 & 0.0000 & 18.54 & 0.0000 \\
\hline $\operatorname{ALM}(\operatorname{Var}(\mathrm{u})=0)$ & 11.58 & 0.0007 & 39.1 & 0.0000 & 51.09 & 0.0000 & 50.11 & 0.0000 \\
\hline \multicolumn{9}{|l|}{ Serial Correlation } \\
\hline LM $\quad($ rho $=0)$ & 423.37 & 0.0000 & 223.99 & 0.0000 & 180.53 & 0.0000 & 173.39 & 0.0000 \\
\hline ALM (rho=0) & 287.51 & 0.0000 & 225.12 & 0.0000 & 211.85 & 0.0000 & 204.95 & 0.0000 \\
\hline \multicolumn{9}{|l|}{ Joint test } \\
\hline $\operatorname{LM}(\operatorname{Var}(\mathrm{u})=0, \mathrm{rho}=0)$ & 434.96 & 0.0000 & 263.09 & 0.0000 & 231.62 & 0.0000 & 223.49 & 0.0000 \\
\hline
\end{tabular}

Source: Own estimates based on BASIS (1995-2001).

The relevance of the model adopted, that contemplates the presence of both serial correlation and random effect is justified by the Bera et al's tests and can be appreciated graphically as follows. Figure 1 contains in circles the observed empirical correlations between $y_{i t}$ and $y_{i, t-s}$, for $s=0,1,2,3$ periods. The graph also shows the implicit correlation in a model with serial correlation and random effects (Model 4), the solid line, with random effect but no serial correlation (the dashed line) and with serial correlation but no random effects (marked with "x"). Clearly, and consistently with the results of the Bera et al's tests, the actual income correlations is better represented by a model with both unobserved heterogeneity and serially correlated error components. 
Figure 1: Correlation structure of the income process in Rural El Salvador

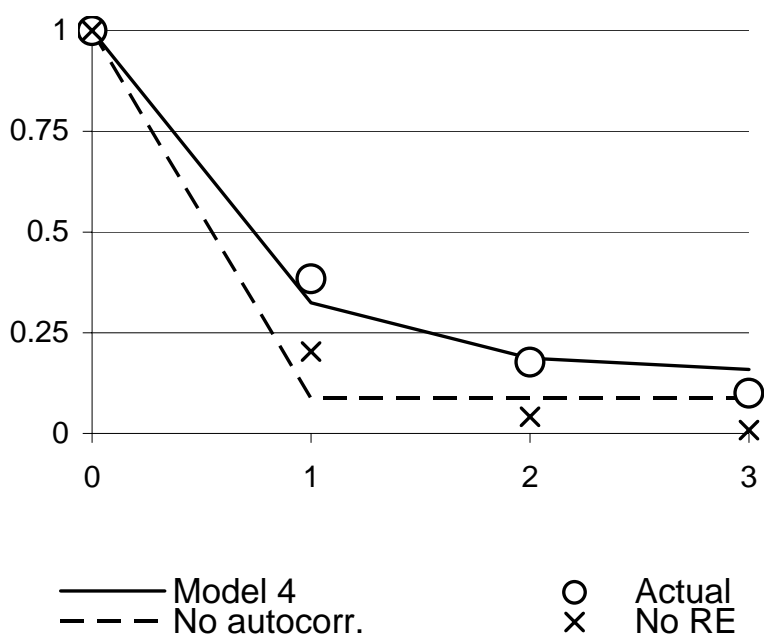

Source: Own estimates based on BASIS (1995-2001).

Table 3 presents estimates of the regression parameters of the autocorrelated model together with the measures of the variance and persistence in incomes. In the basic specification (Model 1), the time dummies explain only 0.030 of the total variation in earnings. The estimated variance of the error components is 0.210 , of which 0.069 corresponds to the variance of the family specific component and 0.140 to the variance of the observation specific, serially correlated term. This latter variance is simply the variance of the underlying white noise process $(0.132)$ "inflated" by the first order serial correlation coefficient (0.238). Hence, in the base model (no explanatory variables), differences in family specific ("permanent") characteristics represent $33.1 \%$ of the dispersion in incomes, which is much lower than the results obtained by Lillard and Willis (73.1\%) and others in the U.S. This is very likely due to the risky nature of rural economic activities and the higher volatility of incomes in developing countries like El Salvador. Hence, the stochastic variation of incomes over time is a key component in explaining differences in incomes across families. 
Table 3: Sources of income persistence in Rural El Salvador

\begin{tabular}{|c|c|c|c|c|c|c|c|c|c|c|c|}
\hline Model & $R^{2}$ & $\sigma_{u}{ }^{2}$ & $\sigma_{\mu}{ }^{2}$ & $\sigma_{\varepsilon}{ }^{2}$ & $\sigma_{v}{ }^{2}$ & $\varphi$ & $\lambda$ & $\rho_{1}$ & $\begin{array}{c}\text { Drop in } \\
\text { variance }\end{array}$ & $\begin{array}{c}\text { Drop in } \\
\text { individual } \\
\text { variance }\end{array}$ & Obs. \\
\hline & (1) & (2) & (3) & (4) & (5) & (6) & (7) & (8) & (9) & $(10)$ & (11) \\
\hline 1 & 0.030 & 0.210 & 0.069 & 0.132 & 0.140 & 0.238 & 0.331 & 0.490 & & & 1636 \\
\hline 2 & 0.161 & 0.174 & 0.035 & 0.131 & 0.139 & 0.234 & 0.201 & 0.388 & $17.1 \%$ & $49.6 \%$ & 1636 \\
\hline 3 & 0.240 & 0.153 & 0.024 & 0.123 & 0.129 & 0.214 & 0.157 & 0.337 & $26.9 \%$ & $65.3 \%$ & 1636 \\
\hline 4 & 0.254 & 0.149 & 0.023 & 0.121 & 0.127 & 0.203 & 0.152 & 0.324 & $28.8 \%$ & $67.3 \%$ & 1636 \\
\hline No Autocorrelation & 0.272 & 0.134 & 0.012 & 0.123 & 0.123 & 0.000 & 0.087 & & & & \\
\hline No Random Effects & 0.254 & 0.127 & 0.000 & 0.121 & 0.127 & 0.203 & 0.000 & & & & \\
\hline
\end{tabular}

Source: Own estimates based on BASIS (1995-2001).

Notes: (1) Overall $R^{2}$, measures the explanatory performance of observed variables; (2) Overall variance of the error term; (3) Variance of the family specific term $\mu$; (4) Variance of the white noise process $\varepsilon ;(5)$ Variance of the observation specific term $v$; (6) Autocorrelation coefficient; (7) Proportion of total variance attributable to family component ((3)/(2)); (8) Adjacent correlation of error term; (9) Drop in overall variance (2) when explanatory variables are added; (10) Drop in family specific variance (3) when explanatory variables are added.

As expected, the addition of explanatory variables drops the overall error variance. For example, when going from model 1 to 2 , the addition of observed income determinants makes the variance drop from .210 to .174 , that is, $17 \%$ of the original variance should be attributable now to measured family characteristics. A similar figure for the family specific term is $49.3 \%$ : of the original family specific variance $(0.069)$ almost half can be explained by measured characteristics. This is remarkably similar to the $44 \%$ obtained by Lillard and Willis.

Let us now turn to the analysis of sources of income persistence. The aggregate adjacent correlation is 0.490 , which gives a rough measure of overall persistence in incomes. The autocorrelation coefficient is 0.238 , which is a measure of the persistence of the observation specific income shocks. Lillard and Willis obtained 0.840 and 0.406 , respectively, in their study. If the only source of persistence were the presence of unobserved heterogeneity among families (no serial correlation), the adjacent correlation would be 0.331 (just the ratio of family specific to total variance). From formula (6), 0.331 can be seen as an asymptotic limit of the correlations (the effect of the "transitory" component vanishes), that is, in the longer term, after the effects of shocks disappear, the correlation among any pair of periods is 0.331 for a given family.

It is important to clarify a distinction advanced in section 2. Going back to the basic model with no explanatory variables, the idiosyncratic observation specific term explains $67 \%$ of the variance of log incomes (beyond the time dummies), the rest being attributable to the family specific components. Consequently, if we are interested in 
explaining differences in incomes, time and observation specific factors play the prime role. Nevertheless, when we focus on income persistence, the adjacent correlation in the basic model is 0.49 , of which 0.33 is due to the role played by time invariant-family specific factors, being the rest attributable to the serially correlated observation specific term. Therefore, when the interest lies on persistence, it is the family specific components that play the key role. The importance of the idiosyncratic shock in explaining income levels is reduced by the relatively low autocorrelation coefficient, as it is clearly expressed in formula (6).

Note that when explanatory variables are deliberately omitted, their effect is captured by each component of the error terms. When the Model 4 is considered, the overall variance of the error term is reduced in around $28 \%$, highlighting the role played by observable factors. The family specific variance drops in around $63 \%$, while the variance of the idiosyncratic shock drops in only $10 \%$, suggesting that the weight of observable factors come from inherently family specific, relatively invariant characteristics. The adjacent correlation of the error term drops to 0.324 , meaning that of the original $0.490,33 \%$ of the persistence is related to the observable factors, $31.02 \%$ to non-observed family specific terms and the rest to the persistence of shocks.

In sum, the results provide significant evidence that: (i) Volatility is the major source of variation in incomes across rural families in El Salvador, much more so than in developed countries. In any given year, the majority of variation in incomes is not accounted for by education or observed family characteristics but instead is due to transitory shocks; (ii) As far as the persistence of incomes over a lifetime, most (around two-thirds) of the persistency in low and high income states is due to idiosyncratic differences between families related to endowments, including unobserved income determinants (unobserved heterogeneity). The persistence of bad shocks is of second order given that the correlation of bad shocks is relatively low (0.24) in these data. So over a lifetime transitory components average out.

As a result, low incomes at any given time in rural El Salvador are strong predictors of low incomes later in life, even controlling for observed family characteristics. In other words, while a large proportion of total cross-section inequality (as measured by the variance of logarithmic incomes) is explained by income instability, life-cycle inequality is largely due to the permanent income component, particularly to relatively time-invariant productive characteristics of families and their members. The latter seem then to be more likely candidate for the existence of poverty traps in Rural El Salvador rather than the inability to insure from income shocks. 


\section{Poverty dynamics}

The previous section explored the sources of persistence in household incomes. The results can be used to quantify the impact of the different factors in relevant features of the distribution of incomes, in particular the proportion of poor households. This section presents results of a simple exercise, with the goal of studying the effects of negative shocks on the poverty status of particular groups. We consider two extensions.

First, as advanced in previous work, in particular Rodríguez-Meza and González-Vega (2004), the distinction between agrarian and non-agrarian households is a key element since the latter group is more diversified. These groups of households likely obey structurally different income patterns so it is worth exploring their dynamics separately. Thus, we divide the sample in "non-agrarian" and "agrarian" based on the activities that families dedicate most of their work hours and estimated the $\operatorname{AR}(1)$ model. Income persistence measures are shown in Table 4 (see basic regression results in Table A.4).

A first relevant result is that the variance of the family error component is now slightly negative. Following Maddala and Mount (1973) this can be prudently interpreted as suggesting zero variances (See Baltagi 2001, pp. 19 for a discussion). One interpretation of this finding is that the income variation in the overall sample can be appropriately summarized by the "agrarian vs. non-agrarian" status, and hence, family income persistence may be arising from high income persistence in one of these groups. In such case the only source of persistence is now due to the serially correlated idiosyncratic error term. In fact, as shown in Table 4, the stochastic term for agrarian households explain a larger fraction of income variation and is also more persistent, as can be appreciated from the estimated autocorrelation coefficients $(0.207$ compared with 0.161 for non-agrarian households). This suggests that agrarian households are more exposed to more persistent shocks in light of having less diversified income sources. 
Table 4. Variance components and persistence, Agrarian and Non-agrarian Households

\begin{tabular}{lrrrrrrrrr}
\hline & $\begin{array}{c}\mathrm{R}^{2} \text { Prais- } \\
\text { Winsten } \\
\text { transf. model }\end{array}$ & $\begin{array}{c}\mathrm{R}^{2} \text { pooled } \\
\text { OLS }\end{array}$ & $\sigma_{u}{ }^{2}$ & $\sigma_{\mu}{ }^{2}$ & $\sigma_{\varepsilon}{ }^{2}$ & $\sigma_{v}{ }^{2}$ & $\varphi$ & $\lambda \quad$ Obs. $^{*}$ \\
\hline Agrarian & 0.124 & 0.137 & 0.161 & 0.000 & 0.154 & 0.161 & 0.207 & 0 & 969 \\
Non agrarian & 0.354 & 0.375 & 0.060 & 0.000 & 0.059 & 0.060 & 0.161 & 0 \\
\hline
\end{tabular}

Source: Own estimates based on BASIS (1995-2001).

* Non balanced panel. Households move from agrarian to non-agrarian activities (See Rodríguez-Meza et al. (2004)). Total agrarian households in estimation sample are 265 in 1995, 250 in 1997, 240 in 1999 , and 214 in 2001

Second, based on the previous estimates we implemented simple simulations of the effect of a large negative shock on poverty dynamics. The exercise is implemented for agrarian and non-agrarian households with low, median and high education, located close to a paved road or far from it. We started by defining a focus household defined by a particular level of the observed explanatory variables (Table A.5 reports the values of the variables set for the simulations). This defines representative households in the two sectors (agrarian, non-agrarian), three levels of education (low, median, high), and two alternative distances to a paved road (close, far). For each of these twelve groups we predicted steady state income distributions as:

$$
y_{i t}=x_{i t}{ }^{\prime} \delta+\mu_{i}+v_{i t}
$$

using the estimated parameters (pooled OLS) and $v_{i t} \sim N\left(0, \frac{\sigma_{\varepsilon}^{2}}{1-\rho^{2}}\right)$. That is, for a given value of $x$, the income of a hypothetical household is generated by computing its predicted long-term income potential as judged by its measured endowments and a random draw from the implied long run distribution of the idiosyncratic error term $v_{i t}$ parameterized as Gaussian. ${ }^{8}$ For this empirical distribution we have computed measures of moderate and extreme poverty rates. These figures appear in the last line of each panel of Table 5 under the SS (steady state) row. For example, the moderate poverty rate for typical agrarian households located close to a paved road and with low education is 0.491 . Of course, within each particular group it is the idiosyncratic error term what varies from household to household. The "steady state" distribution refers to the unconditional, long-run distribution of $v_{i t}$ as implied by the $\operatorname{AR}(1)$ structure, and is

\footnotetext{
${ }^{8}$ Given that the estimated variance of the family error component is null, for the simulations we set the unobserved heterogeneity $\mu_{i}$ equal to zero, as suggested by Maddala and Mount (1973).
} 
to be interpreted as the prevalent distribution after all dynamic adjustments have taken place.

Next we introduced a drastic shock where we shifted the empirical distributions of log-incomes by a negative factor (the first percentile of the distribution of steady state $\left.v_{i t}\right)$. The resulting poverty rates are shown in the first line of each panel of Table 5. For example, for agrarian, low-educated households located close to a paved road, poverty incidence jumps from 0.491 to 0.992 . Then we predicted incomes for subsequent periods by using the estimated $\mathrm{AR}(1)$ structure, computing poverty in each two-year period. Given that the process is stationary, poverty figures should revert back to their long-run levels. As it turns out, it takes approximately 5 periods (approximately 10 years) for low educated, agrarian households to see their poverty rates recovered to their original steady state levels. As expected, the speed of recovery for observationally similar non-agrarian households is much faster. For example, households with low education start with poverty rates above $90 \%$ after the shock, in the first period poverty drops to about $70 \%$ in the agrarian group and to less than $30 \%$ for the more diversified, non-agrarian households. The nature of this particular exercise is rather drastic, and is meant to be suggestive of differences in poverty dynamics in the aftermath of an income shock.

Figure 2 allows us to explore the effects on poverty paths of changes in education and distance to a paved road. An increase in the educational level (percentile 25 to percentile 90) reduces steady state poverty in about 10 percentage points and increases the speed of recovery both for agrarian and non-agrarian households. Reducing the distance to a paved road from 8 to $1 \mathrm{~km}$ has also a strong negative effect on poverty for agrarian households. For non-agrarian households, reducing the distance from percentile 75 to 25 (from 5 to $1 / 2 \mathrm{~km}$ ) has a smaller effect (less than 2 points). In both cases the interaction between distance to paved road and education has a smaller, though significative effect 
Table 5. Simulated Poverty Rates, Agrarian and Non-agrarian Households

Households close to a paved road

\begin{tabular}{|c|c|c|c|c|c|c|}
\hline \multirow[b]{2}{*}{$\begin{array}{l}\text { Moderate Poverty } \\
\text { in year }\end{array}$} & \multicolumn{3}{|c|}{ Agrarian with education } & \multicolumn{3}{|c|}{ Non agrarian with education } \\
\hline & low & median & high & low & median & high \\
\hline 0 & 0.992 & 0.992 & 0.986 & 0.908 & 0.874 & 0.781 \\
\hline 2 & 0.676 & 0.654 & 0.621 & 0.261 & 0.212 & 0.114 \\
\hline 4 & 0.530 & 0.508 & 0.478 & 0.160 & 0.126 & 0.061 \\
\hline 6 & 0.500 & 0.484 & 0.450 & 0.148 & 0.110 & 0.057 \\
\hline 8 & 0.492 & 0.478 & 0.443 & 0.146 & 0.110 & 0.055 \\
\hline 10 & 0.491 & 0.478 & 0.443 & 0.145 & 0.109 & 0.055 \\
\hline 12 & 0.491 & 0.477 & 0.442 & 0.145 & 0.109 & 0.055 \\
\hline 14 & 0.491 & 0.477 & 0.442 & 0.145 & 0.109 & 0.055 \\
\hline 16 & 0.491 & 0.477 & 0.442 & 0.145 & 0.109 & 0.055 \\
\hline 18 & 0.491 & 0.477 & 0.442 & 0.145 & 0.109 & 0.055 \\
\hline SS & 0.491 & 0.477 & 0.442 & 0.145 & 0.109 & 0.055 \\
\hline \multicolumn{7}{|l|}{$\begin{array}{l}\text { Extreme Poverty } \\
\text { in year }\end{array}$} \\
\hline 0 & 0.974 & 0.971 & 0.965 & 0.730 & 0.684 & 0.546 \\
\hline 2 & 0.514 & 0.498 & 0.466 & 0.078 & 0.059 & 0.029 \\
\hline 4 & 0.377 & 0.360 & 0.321 & 0.043 & 0.033 & 0.014 \\
\hline 6 & 0.353 & 0.323 & 0.292 & 0.038 & 0.029 & 0.012 \\
\hline 8 & 0.345 & 0.321 & 0.285 & 0.037 & 0.029 & 0.011 \\
\hline 10 & 0.344 & 0.320 & 0.285 & 0.037 & 0.029 & 0.011 \\
\hline 12 & 0.344 & 0.320 & 0.285 & 0.037 & 0.029 & 0.011 \\
\hline 14 & 0.344 & 0.320 & 0.285 & 0.037 & 0.029 & 0.011 \\
\hline 16 & 0.344 & 0.320 & 0.285 & 0.037 & 0.029 & 0.011 \\
\hline 18 & 0.344 & 0.320 & 0.285 & 0.037 & 0.029 & 0.011 \\
\hline SS & 0.344 & 0.32 & 0.285 & 0.037 & 0.029 & 0.011 \\
\hline
\end{tabular}

\begin{tabular}{|c|c|c|c|c|c|c|}
\hline \multirow[b]{2}{*}{$\begin{array}{l}\text { Moderate Poverty } \\
\text { in year }\end{array}$} & \multicolumn{3}{|c|}{ Agrarian with education } & \multicolumn{3}{|c|}{ Non agrarian with education } \\
\hline & low & median & high & low & median & high \\
\hline 0 & 0.994 & 0.993 & 0.990 & 0.916 & 0.882 & 0.753 \\
\hline 2 & 0.740 & 0.700 & 0.639 & 0.289 & 0.220 & 0.091 \\
\hline 4 & 0.609 & 0.569 & 0.489 & 0.179 & 0.128 & 0.051 \\
\hline 6 & 0.583 & 0.534 & 0.462 & 0.167 & 0.118 & 0.046 \\
\hline 8 & 0.577 & 0.527 & 0.457 & 0.165 & 0.116 & 0.044 \\
\hline 10 & 0.575 & 0.525 & 0.456 & 0.163 & 0.115 & 0.043 \\
\hline 12 & 0.575 & 0.525 & 0.456 & 0.163 & 0.115 & 0.043 \\
\hline 14 & 0.575 & 0.525 & 0.456 & 0.162 & 0.115 & 0.043 \\
\hline 16 & 0.575 & 0.525 & 0.456 & 0.162 & 0.115 & 0.043 \\
\hline 18 & 0.575 & 0.525 & 0.456 & 0.162 & 0.115 & 0.043 \\
\hline SS & 0.575 & 0.525 & 0.456 & 0.162 & 0.115 & 0.043 \\
\hline
\end{tabular}

Extreme Poverty

\begin{tabular}{rllllll} 
in year & \multicolumn{7}{l}{} \\
\hline 0 & 0.985 & 0.980 & 0.970 & 0.757 & 0.687 & 0.508 \\
2 & 0.601 & 0.548 & 0.480 & 0.092 & 0.062 & 0.024 \\
4 & 0.456 & 0.412 & 0.338 & 0.051 & 0.035 & 0.011 \\
6 & 0.426 & 0.384 & 0.304 & 0.046 & 0.030 & 0.011 \\
8 & 0.418 & 0.375 & 0.297 & 0.046 & 0.029 & 0.011 \\
10 & 0.416 & 0.374 & 0.296 & 0.045 & 0.029 & 0.011 \\
12 & 0.415 & 0.374 & 0.296 & 0.045 & 0.029 & 0.011 \\
14 & 0.415 & 0.374 & 0.296 & 0.045 & 0.029 & 0.011 \\
16 & 0.415 & 0.374 & 0.296 & 0.045 & 0.029 & 0.011 \\
18 & 0.415 & 0.374 & 0.296 & 0.045 & 0.029 & 0.011 \\
\hline SS & 0.415 & 0.374 & 0.296 & 0.045 & 0.029 & 0.011 \\
\hline
\end{tabular}

Source: Own estimates based on BASIS (1995-2001).

Note: Education levels low, median and high correspond to percentiles 25, 50 and 90 respectively. Distance to a paved road is close (percentile 25) or far (percentile 75). 
Figure 2. Simulated effects on poverty rates of changes in education and distance to a paved
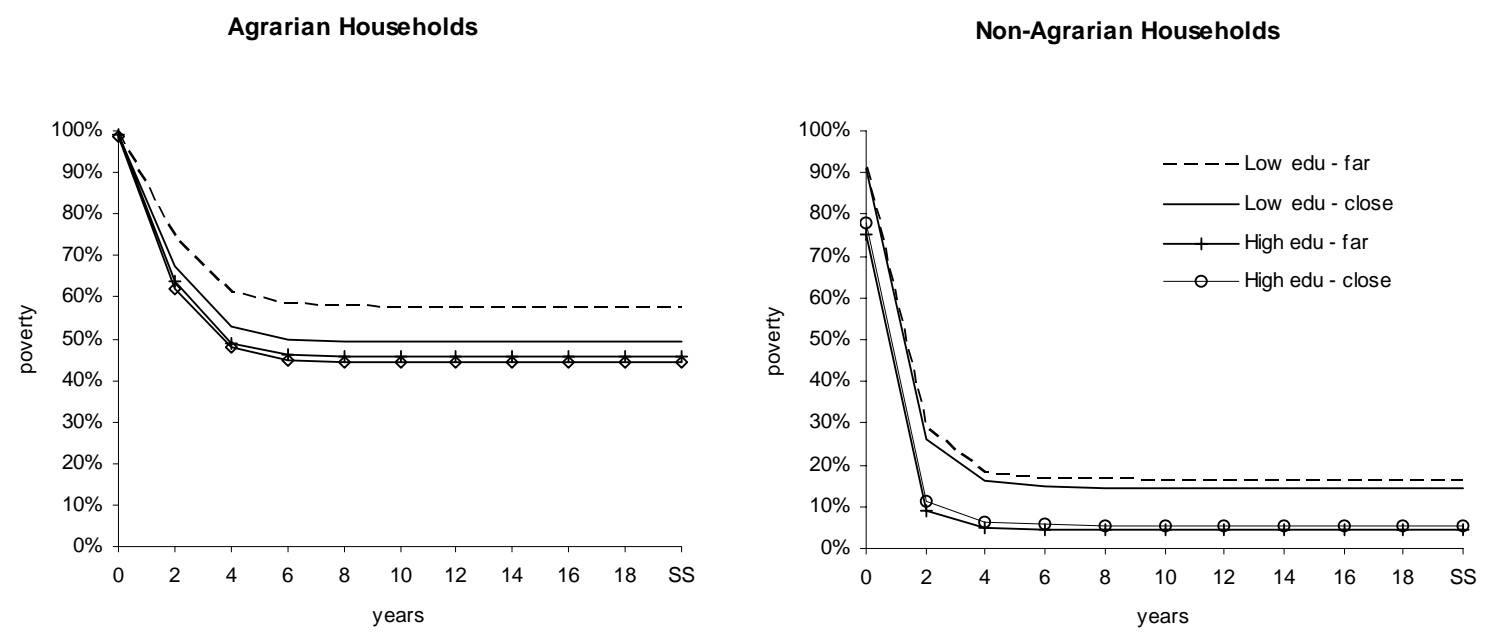

Source: Own estimates based on BASIS (1995-2001).

\section{Conclusions}

We use a unique panel dataset (1995-2001) of rural El Salvador to investigate the main sources of the persistence and variability of incomes. The paper investigates the extent to which families are continuously poor due to endowments (observed and unobserved) that yield low income potential or due to systematic income shocks that they are unable to smooth. We follow the approach that was first pioneered by Lillard and Willis (1978) to study income mobility in the U.S. who main appealing features has withstood scrutiny in subsequent studies. We implement testing procedures proposed by Bera, Yoon and Sosa Escudero (2001) robust test for presence of unobserved heterogeneity, state dependence or both based on a 'null' model of no persistency, and find evidence supporting the validity of the Lillard and Willis (1978) basic model specification.

Our main results are that being persistently low income or poor in rural El Salvador is largely a result of starting and continuing with unfavorable endowments or characteristics and to some extent to past "bad luck". Observed income determinants account for about half of this income persistence. Controlling for unobserved heterogeneity leaves little room for pure state dependence. The analysis indicates that some of the main culprits are manipulable by policy interventions, although many not in the short term. For example, investments in rural roads can facilitate the diversification 
of families from subsistence agriculture to more dynamic agricultural or off-farm activities in a relatively short span. However, education is a chief source of attraction to low income states since it can take one or two decades for a family to break the intergenerational transmission of low education. In further extensions of this work we plan to further quantify the role of these measured factors and their interactions in the generation of income persistence. 


\section{References}

Abowd, J., and D. Card 1989. "On the Covariance Structure of Earnings and Hours Changes," Econometrica, 57, 411-445.

Antman, F. and D. Mckenzie. 2005. "Poverty traps and non-linear dynamics with measurement error and individual heterogeneity", mimeo, Stanford University.

Anderson, T. and C. Hsiao. 1982. "Estimation of dynamic models with errorcomponents", Journal of Econometrics, 18, 47-82.

Arellano, M. 2003. Panel Data Econometrics, Oxford University Press, Oxford.

Arellano, M. and S. Bond. 1991. "Some specification tests for panel data: Monte Carlo evidence and an application to employment equations", Review of Economic Studies, 58, 277-297.

Azariadis, C., and J. Stachurski. 2005. "Poverty Traps." In Handbook of Economic Growth, ed. P. Aghion and S. Durlauf. North Holland. 204

Baltagi, B. 2001. Econometric Analysis of Panel Data, Wiley, New York.

Beneke de Sanfeliu, M., and M. Shi. 2004. "Dinámica del Ingreso en El Salvador." Serie de Investigación 2. Antiguo Cuscatlán: Departamento de Estudios Económicos y Sociales (DEES)/FUSADES.

Bera, A., W. Sosa Escudero, and M. Yoon. 2001. "Tests for the error component model under local misspecification", Journal of Econometrics, 101, 1-23.

Blanchard, O., and L. Katz. 1992. "Regional Evolutions." Brookings Papers on Economic Activity, 32, 159-85.

Chaudhuri, S. 2000. "Empirical Methods for Assessing Household Vulnerability to Poverty." School of International and Public Affairs, Columbia University, New York.

Chaudhuri, S., J. Jalan, and A. Suryahadi. 2002. "Assessing Household Vulnerability to Poverty: A Methodology and Estimates for Indonesia.” Department of Economics Discussion Paper 0102-52, Columbia University, New York.

Fields, G., R. Duval, S. Freije, and M. Puerta. 2005. "Earnings Mobility in Argentina, Mexico, and Venezuela: Testing the Divergence of Earnings and the Symmetry of Mobility Hypotheses.” Unpublished paper, Cornell University, Ithaca, NY.

Freije, S., and A. Souza. 2002. "Earnings Dynamics and Inequality in Venezuela: 19951997." Working Paper 0211, Vanderbilt University, Department of Economics, Nashville, TN. 
Friedman, M. 1962. "Capitalism and Freedom.” Princeton, NJ: Princeton University.

Friedman, M. and S. Kuznets. 1954. "Incomes from Independent Professional Practice." National Bureau of Economic Research, New York (1945), 1954.

Galiani, S., C. Lamarche, A. Porto, and W. Sosa Escudero. 2005. "Persistence and Regional Disparities in Unemployment: Argentina 1980-1981”, Regional Science and Urban Economics, 35, 375-394.

Geweke, J., and M. Keane. 2000. "An Empirical Analysis of Income Dynamics among Men in the PSID: 1968-1989." Journal of Econometrics 96: 293-356.

Gottschalk, P., and R.A. Moffitt. 1994. "Welfare Dependence: Concepts, Measures, and Trends," American Economic Review. American Economic Association, vol. 84(2), pages 38-42, May.

Hendry, D.F. and G.E. Mizon. 1978. "Serial correlation as a convenient simplification, not a nuisance: A comment on a study of the demand for money by the Bank of England", Economic Journal, 88, 549-563.

Holtz-Eakin, D. 1988. "Testing for individual effects in autorregresive models", Journal of Econometrics, 39, 297-307.

Horowitz J.L. and M. Markatou. 1996. "Semiparametric estimation of regression models for panel data", Review of Economic Studies 63, 145-168.

Jalan, J., and M. Ravallion. 1999. "Income Gains to the Poor from Workfare: Estimates for Argentina's Trabajar Program.” Policy Research Working Paper 2149, World Bank, Washington, DC.

Jimenez-Martin, S. 1998. "On the testing of heterogeneity effects in dynamic unbalanced panel data models", Economic Letters, 58, 157-163.

Judson, R. and A. Owen. 1999. "Estimating dynamic panel data models: a guide for macroeconomists", Economic Letters, 65, 9-15.

Lanjouw, P. 2001. "Nonfarm Employment and Poverty in Rural El Salvador." World Development 29 (3): 529-47.

Lillard, L. and R. Willis. 1978. "Dynamic aspects of earning mobility", Econometrica, 46, 985-1012.

MaCurdy, T. 1982. "The use of time series processes to model the error structure of earnings in a longitudinal data analysis", Journal of Econometrics, 18, 83-114. 
Maddala, G.S. and T. Mount. 1973. "A comparative study of alternative estimators for variance components models used in econometric applications", Journal of the American Statistical Association, 68, 324-328.

McCall, J.J. 1973. Income Mobility, Racial Discrimination, and Economic Growth. Lexington Books, Lexington, MA. Redner, R.A., Walker, H.F., 1984.

Meghir, C. and L. Pistaferri. 2002. "Income Variance Dynamics and Heterogeneity," CEPR Discussion Papers 3632, C.E.P.R. Discussion Papers.

Newhouse, D. 2005. "The Persistence of Income Shocks: Evidence from Rural Indonesia", Review of Development Economics 9 (3), 415-433.

Pritchett, L., A. Suryahadi, and S. Sumarto. 2000. "Quantifying Vulnerability to Poverty. A Proposed Measure Applied to Indonesia.” Policy Research Working Paper 2437, World Bank, Washington, DC.

Ravallion, M., and S. Chaudhuri. 1997. "Risk and Insurance in Village India: A Comment." Econometrica 65 (1): 171-84.

Ravallion, M. and M. Lokshin, 2004. "Household Income Dynamics in Two Transition Economies." Studies in Nonlinear Dynamics \& Econometrics, Berkeley Electronic Press, vol. 8 (3)

Rodríguez-Meza, J., and C. González-Vega. 2004. "Household Income Dynamics and Poverty Traps in El Salvador." Paper written for AAEA (American Agriculture Economists Association) annual meeting, Ohio State University, Columbus.

Tannuri-Pianto, M., D. Pianto, O. Arias, and M. Beneke de Sanfeliu. 2005. "Determinants and Returns to Productive Diversification in Rural El Salvador." Background paper for the Beyond the City: The Rural Contribution to Development, World Bank, Washington, DC.

Welch, F. 1999. In defense of inequality, American Economic Review, Papers and Proceedings, May.

World Bank. 2005. "El Salvador Poverty Assessment: Strengthening Social Policy." Report 29594-SV. World Bank, Washington, DC.

Zincenko, F. 2005. "The power of panel tests for serial correlation under dynamic misspecification", mimeo, Universidad de San Andrés 


\section{Appendix}

Table A.1. Definition of variables

\begin{tabular}{|c|c|}
\hline Variables & Definition \\
\hline Log income (dep. var.) & Log of per capita household income \\
\hline Education & Average years of education of members in the labor force (imputed) \\
\hline Workers & Log of workers per capita \\
\hline Children and elderly & Log of number of children and elderly \\
\hline Non agrarian & $=1$ if main household activity is non agricultural \\
\hline Microenterprises & Number of microenterprises \\
\hline Paved Road & Distance to paved road (in $\mathrm{km}$ ) \\
\hline Formal Credit & $=1$ if household received formal credit \\
\hline Other Credit & $=1$ if household received other credit \\
\hline Remittances & Log of remittances \\
\hline Subsidies & Log of subsidies from the Government \\
\hline Interactions w/ Education & and Formal Credit, Other Credit, Remittances and Subsidies \\
\hline Interactions w/ Paved Road & and Formal Credit, Other Credit, Remittances, Subsidies and Education \\
\hline Geographic controls & $\begin{array}{l}\text { Region reported in the first interview (West, South Central, North Central, South } \\
\text { Eastern and North Eastern) }\end{array}$ \\
\hline
\end{tabular}

Table A.2. Descriptive statistics in Estimation Sample

\begin{tabular}{|l|c|c|c|c|}
\hline Variables & $\mathbf{1 9 9 5}$ & $\mathbf{1 9 9 7}$ & $\mathbf{1 9 9 9}$ & $\mathbf{2 0 0 1}$ \\
\hline Log income (dep. var.) & 9.282 & 9.295 & 9.418 & 9.454 \\
& & & & \\
Education & 3.647 & 3.704 & 4.030 & 3.877 \\
Workers & -0.962 & -0.860 & -0.730 & -0.625 \\
Children and elderly & 0.860 & 0.880 & 0.857 & 0.844 \\
& & & & \\
Non agrarian & $35.2 \%$ & $38.9 \%$ & $41.3 \%$ & $47.7 \%$ \\
Microenterprises & 0.117 & 0.230 & 0.352 & 0.435 \\
Paved Road & 5.478 & 5.239 & 4.922 & 3.697 \\
Formal Credit & $4.9 \%$ & $8.6 \%$ & $1.2 \%$ & $0.5 \%$ \\
Other Credit & $9.0 \%$ & $23.0 \%$ & $24.7 \%$ & $38.1 \%$ \\
Remittances & 1.566 & 1.867 & 3.116 & 3.865 \\
Subsidies & 1.190 & 1.008 & 0.795 & 2.491 \\
& & & & \\
Western Region & $25.4 \%$ & $25.4 \%$ & $25.4 \%$ & $25.4 \%$ \\
South Central Region & $30.3 \%$ & $30.3 \%$ & $30.3 \%$ & $30.3 \%$ \\
North Central Region & $13.2 \%$ & $13.2 \%$ & $13.2 \%$ & $13.2 \%$ \\
South Eastern Region & $16.9 \%$ & $16.9 \%$ & $16.9 \%$ & $16.9 \%$ \\
North Eastern Region & $14.2 \%$ & $14.2 \%$ & $14.2 \%$ & $14.2 \%$ \\
\hline Number of households & & & & \\
\hline
\end{tabular}


Table A.3. Alternative models.

\begin{tabular}{|l|c|c|c|c|}
\hline Variables & Model 1 & Model 2 & Model 3 & Model 4 \\
\hline Education & & $\mathrm{X}$ & $\mathrm{X}$ & $\mathrm{X}$ \\
Workers & & $\mathrm{X}$ & $\mathrm{X}$ & $\mathrm{X}$ \\
Children and elderly & & $\mathrm{X}$ & $\mathrm{X}$ & $\mathrm{X}$ \\
\hline Non agrarian & & & $\mathrm{X}$ & $\mathrm{X}$ \\
Microenterprises & & & $\mathrm{X}$ & $\mathrm{X}$ \\
Paved Road & & & $\mathrm{X}$ & $\mathrm{X}$ \\
Paved Road squared & & & $\mathrm{X}$ & $\mathrm{X}$ \\
Formal Credit & & & $\mathrm{X}$ & $\mathrm{X}$ \\
Other Credit & & & $\mathrm{X}$ & $\mathrm{X}$ \\
Remittances & & & $\mathrm{X}$ & $\mathrm{X}$ \\
Subsidies & & & $\mathrm{X}$ & $\mathrm{X}$ \\
\hline Interactions w/ Education & & & & $\mathrm{X}$ \\
Interactions w/ Paved Road & & & & $\mathrm{X}$ \\
\hline Geographic controls & & $\mathrm{X}$ & $\mathrm{X}$ & $\mathrm{X}$ \\
Year controls & $\mathrm{X}$ & $\mathrm{X}$ & $\mathrm{X}$ & $\mathrm{X}$ \\
\hline
\end{tabular}


Table A.4. Regression results

Dependent variable: Log of per capita household income Pooled OLS estimates

\begin{tabular}{|c|c|c|c|}
\hline & & Agrarian & Non agrarian \\
\hline & Education & $\begin{array}{l}0.002 \\
(0.21)\end{array}$ & $\begin{array}{l}0.015 \\
(2.40)^{\star}\end{array}$ \\
\hline & Workers & 0.118 & 0.149 \\
\hline & & $(3.93)^{\star \star}$ & $(5.96)^{\star \star}$ \\
\hline & Children and elderly & -0.053 & -0.122 \\
\hline & & $(2.07)^{\star}$ & $(5.53)^{\star \star}$ \\
\hline & Microenterprises & 0.064 & 0.073 \\
\hline & & $(1.70)$ & $(4.31)^{\star \star}$ \\
\hline & Paved Road & -0.021 & -0.010 \\
\hline & & $(3.57)^{\star \star}$ & (1.48) \\
\hline & Paved Road squared & 0.001 & 0.000 \\
\hline & & $(2.91)^{\star \star}$ & $(0.98)$ \\
\hline & Formal Credit & 0.060 & -0.023 \\
\hline & & $(0.40)$ & $(0.18)$ \\
\hline & Other Credit & -0.080 & -0.119 \\
\hline & & $(1.24)$ & $(2.14)^{\star}$ \\
\hline & Remittances & -0.025 & 0.000 \\
\hline & & $(4.12)^{\star \star}$ & $(0.01)$ \\
\hline & Subsidies & -0.009 & -0.019 \\
\hline & & $(0.92)$ & $(2.24)^{\star}$ \\
\hline \multirow[t]{6}{*}{$\begin{array}{l}\text { Interactions w/ } \\
\text { Education }\end{array}$} & Formal Credit & $\begin{array}{l}0.038 \\
(1.37)\end{array}$ & $\begin{array}{l}0.017 \\
(1.08)\end{array}$ \\
\hline & Other Credit & 0.021 & 0.025 \\
\hline & & $(1.57)$ & $(2.70)^{\star \star}$ \\
\hline & Remittances & 0.003 & 0.001 \\
\hline & & $(2.15)^{\star}$ & (1.07) \\
\hline & Subsidies & $\begin{array}{l}-0.000 \\
(0.23)\end{array}$ & $\begin{array}{l}0.001 \\
(0.84)\end{array}$ \\
\hline \multirow{14}{*}{$\begin{array}{l}\text { Interactions w/ Paved } \\
\text { Road }\end{array}$} & Formal Credit & -0.018 & -0.002 \\
\hline & & $(1.23)$ & $(0.27)$ \\
\hline & Other Credit & 0.000 & -0.000 \\
\hline & & $(0.03)$ & $(0.05)$ \\
\hline & Remittances & 0.001 & 0.000 \\
\hline & & $(2.30)^{\star}$ & $(0.44)$ \\
\hline & Subsidies & 0.000 & 0.001 \\
\hline & & $(0.05)$ & $(0.92)$ \\
\hline & Education & 0.002 & 0.002 \\
\hline & & $(2.00)^{\star}$ & $(2.17)^{\star}$ \\
\hline & Constant & 9.401 & 9.586 \\
\hline & & $(158.60)^{\star \star}$ & $(179.37)^{\star \star}$ \\
\hline & Observations & 969 & 667 \\
\hline & R-squared & 0.14 & 0.38 \\
\hline
\end{tabular}

Absolute value of $\mathrm{t}$ statistics in parentheses. * significant at 5\%; ** significant at $1 \%$ Note: geographic and year controls omitted in the table. 
Table A.5. Values used in the simulations

\begin{tabular}{lrr}
\hline Variables & Agrarian & Non-agrarian \\
\hline Education & & \\
$\quad$ low (percentile 25) & 1.00 & 2.67 \\
$\quad$ median (percentile 50) & 3.00 & 4.50 \\
$\quad$ high (percentile 90) & 6.60 & 9.00 \\
\hline Paved Road $\quad$ close (percentile 25) & 1.00 & \\
$\quad$ far (percentile 75) & 8.00 & 0.40 \\
Workers (mean) & -0.77 & 5.00 \\
Children and elderly (mean) & 0.87 & -0.83 \\
Microenterprises (mean) & 0.13 & 0.85 \\
Formal Credit (min) & 0 & 0.51 \\
Other Credit (min) & 0 & 0 \\
Remittances (mean) & 2.80 & 0 \\
Subsidies (mean) & 1.38 & 2.32 \\
Western Region (other regions $=0)$ & 1 & 1.36 \\
Year 2001 (other years = 0) & 1 & 1 \\
&
\end{tabular}




\section{SERIE DOCUMENTOS DE TRABAJO DEL CEDLAS}

Todos los Documentos de Trabajo del CEDLAS están disponibles en formato electrónico en $<w w w$.depeco.econo.unlp.edu.ar/cedlas $>$.

- Nro. 37 (Junio, 2006). Walter Sosa-Escudero, Mariana Marchionni y Omar Arias. "Sources of Income Persistence: Evidence from Rural El Salvador".

- Nro. 36 (Mayo, 2006). Javier Alejo. "Desigualdad Salarial en el Gran Buenos Aires: Una Aplicación de Regresión por Cuantiles en Microdescomposiciones".

- Nro. 35 (Abril, 2006). Jerónimo Carballo y María Bongiorno. "La Evolución de la Pobreza en Argentina: Crónica, Transitoria, Diferencias Regionales y Determinantes (1995-2003)".

- Nro. 34 (Marzo, 2006). Francisco Haimovich, Hernán Winkler y Leonardo Gasparini. "Distribución del Ingreso en América Latina: Explorando las Diferencias entre Países".

- Nro. 33 (Febrero, 2006). Nicolás Parlamento y Ernesto Salinardi. "Explicando los Cambios en la Desigualdad: Son Estadísticamente Significativas las Microsimulaciones? Una Aplicación para el Gran Buenos Aires".

- Nro. 32 (Enero, 2006). Rodrigo González. "Distribución de la Prima Salarial del Sector Público en Argentina".

- Nro. 31 (Enero, 2006). Luis Casanova. "Análisis estático y dinámico de la pobreza en Argentina: Evidencia Empírica para el Periodo 1998-2002".

- Nro. 30 (Diciembre, 2005). Leonardo Gasparini, Federico Gutiérrez y Leopoldo Tornarolli. "Growth and Income Poverty in Latin America and the Caribbean: Evidence from Household Surveys".

- Nro. 29 (Noviembre, 2005). Mariana Marchionni. "Labor Participation and Earnings for Young Women in Argentina".

- $\quad$ Nro. 28 (Octubre, 2005). Martín Tetaz. "Educación y Mercado de Trabajo".

- Nro. 27 (Septiembre, 2005). Matías Busso, Martín Cicowiez y Leonardo Gasparini. "Ethnicity and the Millennium Development Goals in Latin America and the Caribbean".

- Nro. 26 (Agosto, 2005). Hernán Winkler. "Monitoring the Socio-Economic Conditions in Uruguay".

- Nro. 25 (Julio, 2005). Leonardo Gasparini, Federico Gutiérrez y Guido G. Porto. "Trade and Labor Outcomes in Latin America's Rural Areas: A Cross-Household Surveys Approach". 
- Nro. 24 (Junio, 2005). Francisco Haimovich y Hernán Winkler. "Pobreza Rural y Urbana en Argentina: Un Análisis de Descomposiciones".

- Nro. 23 (Mayo, 2005). Leonardo Gasparini y Martín Cicowiez. "Equality of Opportunity and Optimal Cash and In-Kind Policies".

- Nro. 22 (Abril, 2005). Leonardo Gasparini y Santiago Pinto. "Equality of Opportunity and Optimal Cash and In-Kind Policies".

- Nro. 21 (Abril, 2005). Matías Busso, Federico Cerimedo y Martín Cicowiez. "Pobreza, Crecimiento y Desigualdad: Descifrando la Última Década en Argentina".

- Nro. 20 (Marzo, 2005). Georgina Pizzolitto. "Poverty and Inequality in Chile: Methodological Issues and a Literature Review".

- Nro. 19 (Marzo, 2005). Paula Giovagnoli, Georgina Pizzolitto y Julieta Trías. "Monitoring the Socio-Economic Conditions in Chile".

- Nro. 18 (Febrero, 2005). Leonardo Gasparini. "Assessing Benefit-Incidence Results Using Decompositions: The Case of Health Policy in Argentina".

- Nro. 17 (Enero, 2005). Leonardo Gasparini. "Protección Social y Empleo en América Latina: Estudio sobre la Base de Encuestas de Hogares".

- Nro. 16 (Diciembre, 2004). Evelyn Vezza. "Poder de Mercado en las Profesiones Autorreguladas: El Desempeño Médico en Argentina".

- Nro. 15 (Noviembre, 2004). Matías Horenstein y Sergio Olivieri. "Polarización del Ingreso en la Argentina: Teoría y Aplicación de la Polarización Pura del Ingreso".

- Nro. 14 (Octubre, 2004). Leonardo Gasparini y Walter Sosa Escudero. "Implicit Rents from Own-Housing and Income Distribution: Econometric Estimates for Greater Buenos Aires".

- Nro. 13 (Septiembre, 2004). Monserrat Bustelo. "Caracterización de los Cambios en la Desigualdad y la Pobreza en Argentina Haciendo Uso de Técnicas de Descomposiciones Microeconometricas (1992-2001)".

- Nro. 12 (Agosto, 2004). Leonardo Gasparini, Martín Cicowiez, Federico Gutiérrez y Mariana Marchionni. "Simulating Income Distribution Changes in Bolivia: a Microeconometric Approach".

- Nro. 11 (Julio, 2004). Federico H. Gutierrez. "Dinámica Salarial y Ocupacional: Análisis de Panel para Argentina 1998-2002".

- Nro. 10 (Junio, 2004). María Victoria Fazio. "Incidencia de las Horas Trabajadas en el Rendimiento Académico de Estudiantes Universitarios Argentinos".

- Nro. 9 (Mayo, 2004). Julieta Trías. "Determinantes de la Utilización de los Servicios de Salud: El Caso de los Niños en la Argentina". 
- Nro. 8 (Abril, 2004). Federico Cerimedo. "Duración del Desempleo y Ciclo Económico en la Argentina".

- Nro. 7 (Marzo, 2004). Monserrat Bustelo y Leonardo Lucchetti. "La Pobreza en Argentina: Perfil, Evolución y Determinantes Profundos (1996, 1998 Y 2001)".

- Nro. 6 (Febrero, 2004). Hernán Winkler. "Estructura de Edades de la Fuerza Laboral y Distribución del Ingreso: Un Análisis Empírico para la Argentina".

- Nro. 5 (Enero, 2004). Pablo Acosta y Leonardo Gasparini. "Capital Accumulation, Trade Liberalization and Rising Wage Inequality: The Case of Argentina".

- Nro. 4 (Diciembre, 2003). Mariana Marchionni y Leonardo Gasparini. "Tracing Out the Effects of Demographic Changes on the Income Distribution. The Case of Greater Buenos Aires".

- Nro. 3 (Noviembre, 2003). Martín Cicowiez. "Comercio y Desigualdad Salarial en Argentina: Un Enfoque de Equilibrio General Computado".

- Nro. 2 (Octubre, 2003). Leonardo Gasparini. "Income Inequality in Latin America and the Caribbean: Evidence from Household Surveys".

- Nro. 1 (Septiembre, 2003). Leonardo Gasparini. "Argentina's Distributional Failure: The Role of Integration and Public Policies". 